\title{
English-Polish contrastive grammar at Polish universities
}

\author{
Elżbieta Mańczak-Wohlfeld \\ Jagiellonian University, Poland
}

\begin{abstract}
Although contrastive studies do not enjoy great prestige among linguists, they have a very long tradition dating back to ca. 1000 A.D. when Ælfric wrote his Grammatica, a grammar of Latin and English. Even then he must have been aware of the fact that the knowledge of one language may be helpful in the process of learning another language (Krzeszowski 1990). Similarly, it seems that throughout the history of mankind teachers of a foreign language must have realized that a native and foreign tongue can be contrasted. However, contrastive linguistics only came into being as a science at the turn of the $19^{\text {th }}$ and $20^{\text {th }}$ centuries. The first works were almost purely theoretical, and it is worth emphasizing that among the first scholars working in the field was Baudouin de Courtenay, a Polish linguist, who published his contrastive grammar of Polish, Russian and Old Church Slavonic in 1912. The outbreak of the Second World War was a milestone in the development of applied contrastive studies since a need to teach foreign languages in the United States arose as a result. The 1960's is considered a further step in the development of contrastive grammar since a number of projects were initiated both in Europe and in the U.S.A. (Willim, Mańczak-Wohlfeld 1997), which resulted in the introduction of courses in EnglishPolish contrastive grammar at Polish universities. The aim of the present paper is to characterize and evaluate the courses offered in the English departments of selected Polish universities and to suggest an "ideal" syllabus.
\end{abstract}

Keywords: contrastive studies, teaching contrastive grammar, course descriptions

\section{Introductory remarks}

I would like to start the present paper with a statement put forward by the late Professor Walerian Świeczkowski from the Maria Curie-Skłodowska University in Lublin. The statement was expressed at a Ph.D. seminar held at Warsaw University in the mid-1970s, when I was a student there. According to the Professor's firm belief Polish linguists specializing in English should concentrate on English-Polish contrastive grammar since they are the only linguists who are able to contribute to this particular field of studies. At the time this type of research was particularly popular among Polish anglicists, a fact which does not mean that there is no interest in the field today and it goes without saying that the research should be reflected in the process of teaching. Having said that, although contrastive studies 
do not enjoy great prestige among present day linguists, they have a very long tradition that dates back to ca. 1000 A.D. when Ælfric wrote his Grammatica, a grammar of Latin and English. Even then, he must have been aware of the fact that the knowledge of one language may be helpful in the process of learning another (Krzeszowski 1990). Similarly, it seems that throughout the history of mankind teachers of a foreign language must have realized that a native and foreign tongue can be contrasted. However, contrastive studies of a sort (without the term being used) have been carried out since the $15^{\text {th }}$ century and the first "theories" were formulated at the beginning of the $17^{\text {th }}$ century. It was then that John Hewes stated that a knowledge of one's first language may not only facilitate the learning of a foreign tongue but can equally well hinder it due to, what was called much later, negative transfer (Krzeszowski 2011). However, contrastive linguistics only came into being as a science at the turn of the $19^{\text {th }}$ and $20^{\text {th }}$ centuries. Unlike the above mentioned achievements the first works were almost purely theoretical although it is worth emphasizing that among the first scholars working in the field was Baudouin de Courtenay, a Polish linguist, who published his contrastive grammar of Polish, Russian and Old Church Slavonic in 1912. The Prague school of linguistics followed his lead, particularly such academics as V. Mathesius, B. Trnka, and J. Vachek. The outbreak of the Second World War was a milestone in the development of applied contrastive studies since a need to teach foreign languages in the United States arose as a result. The 1960's is considered a further step in the development of contrastive grammar since a number of projects were initiated both in Europe and in the U.S.A. (Willim, MańczakWohlfeld 1997), which resulted in the introduction of courses in English-Polish contrastive grammar at Polish universities. Thus, the aim of the present paper is to characterize and evaluate the courses offered at the English departments of selected Polish universities and to suggest an "ideal" syllabus.

The study has been restricted to Polish universities, which means that vocational schools have not been included. This is due to the space and time limitation. Today, there are altogether nineteen universities in Poland, although in some either the course is not offered or it is impossible to obtain any information concerning it on the Internet or even via personal communication. However, most of the material relating to teaching English-Polish contrastive grammar is taken from web pages (a list is provided in the References) or personal contacts, for which I would like to express my sincere gratitude.

\section{The National Qualifications Framework and learning outcomes}

In the following discussion I do not consider the National Qualifications Framework and learning outcomes since on the one hand, they represent, what I call educational "Newspeak", and on the other, if they are available at all, it seems they have a lot in common with each other. However, it is worth quoting an example taken from the University of Wrockaw (Department of English Studies): 


\section{Learning outcomes}

\section{KNOWLEDGE}

01. The student is knowledgeable about the objectives and methods used in comparative linguistics research. The student understands the workings of language as a grammatical system that consists of phonological, morphosyntactic and semantic modules.

02. The student is aware of morphological and syntactic processes occurring in Polish and in English (e.g. word derivation, compounding), and can explain the specific mechanisms that are at work in both languages.

03. The student knows the theory of principles and parameters that is applied to explain differences in grammatical systems across languages; $s /$ he is able to provide examples of language universals and explain the ways parameters are set and reflect cross-linguistic variation.

04. The student is aware of grammatical phenomena in English and Polish which due to their cross-linguistic divergence are particularly problematic in the process of EnglishPolish translation, learning, and teaching.

05. The student knows the basic terminology used in linguistics.

06. The student has an extensive knowledge of phonological, lexical, and morphosyntactic properties of the English language as well as their historical development. The student is able to make informed statements about linguistic structures that are found in Polish and English and is able to provide equivalents of these structures in both languages.

\section{SKILLS}

01. The student is able to use the knowledge of English and Polish grammar in the process of learning, teaching and translation.

02. The student can analyze grammatical phenomena that are expressed differently in Polish and English (e.g. tense and aspect) or that do not exist in one of the languages (e.g. definiteness in Polish) and is able to take informed choices while translating texts that involve these grammatical phenomena.

03. The student is able to analyze new language borrowings (anglicisms) and evaluate their adaptation in the Polish language.

\section{SOCIAL COMPETENCE}

01. The student understands the need for lifelong learning, especially in relation to the development of language skills.

02. The student is able to work in a team, adopt different roles in a group, and share his/her knowledge and skills with others.

03. The student knows how to set priorities, is able to manage time and accomplish specific tasks within given deadlines.

Since no assessment criteria are provided, as an illustration I will use those from my own university: 


\section{KNOWLEDGE}

Knowledge of the topics in comparative linguistics, English grammar and English-Polish contrastive grammar covered in the course - NFEn1A_WO2 i NFEn1A_WO3 - is evaluated on the basis of the assessment of a student's preparation for class and their active participation in class discussions to check the understanding of course reading materials as well as on the basis of performance in the end of the semester test and final exam.

\section{SKILLS}

NFEn1A_UO6 is evaluated on the basis of the students' ability to do tasks assigned by the instructor, to analyze new problems in class and to provide explanations/commentary.

\section{SOCIAL COMPETENCE}

NFEn1A_KO1 is developed and evaluated through continual work on home assignments throughout the course, the end of semester test and the final exam.

\section{Course description}

An analysis of the courses on English-Polish contrastive grammar offered at Polish universities has revealed the following: three universities do not offer this course despite the fact that they have a number of other courses in English linguistics in the first cycle. ${ }^{1}$ This is the case with respect to the University of Gdansk where such subjects as Introduction to linguistics, Syntax and pragmatics, Phonetics, phonology and morphology, and Semantics as well as History of English are taught. This is true of the Maria Curie-Skłodowska University in Lublin which offers the following linguistics courses: Introduction to linguistics, Descriptive grammar, History of English, and American English as well as to the University of Szczecin where Syntax, Morphology, Pragmatics, Sociolinguistics, and Global English/ELF are given. In the case of two other universities (Bydgoszcz and Rzeszów) the course is offered, as can be seen on the Internet, however, unfortunately there is no access to a description. Despite this it can be deduced that the Chair of English Studies in Bydgoszcz offers 15 hours of lectures and 15 hours of classes during the sixth semester and grants 2 ECTS points, although not even this information is available on the web page of the Institute of English Philology in Rzeszów - just the fact that the course itself does exist as noted above. There is no information concerning the linguistics programme in the case of two other universities; namely the Jan Kochanowski University in Kielce, although the Faculty of Language Studies and History is located at the University's Branch in Piotrków Trybunalski which includes the English Department and the Chair of English Philology at the University of Zielona Góra. All in all, it may be concluded that of the nineteen Polish universities which conduct English studies, only twelve can be included in the present analysis.

What follows are several fragments from the course descriptions for English-Polish contrastive grammar. They present differences between the contents of the syllabi offered at various Polish universities, which reflect diverse research interests of lecturers who teach the

1 The course is usually offered at BA level. 
course in question as well as show different degree of detail in the description of the content of the course in the syllabi under discussion. While some of them (as shown in sections 3.4., 3.5., or 3.10.) give an exhaustive list of topics to be covered during each teaching unit, others (e.g. in sections 3.7. and 3.8.) contain less precise statements, thus leaving the final choice of the material to be discussed by the lecturer. Besides, it has to be stressed that despite the tendency to internationalize university courses in this country in some cases the syllabi are only in Polish. In such instances I provide my own translation, with the original version in the footnotes.

\subsection{The Adam Mickiewicz University in Poznań, Faculty of English ${ }^{2}$}

The course is obligatory in academic and translation specializations. Year 2, 30 contact hours, 3 ECTS points. Students who specialize in teaching do not take this course, a decision with which some might disagree.

The aim of this course is to provide students with a set of tools that will enable them to analyze and compare languages with respect to their structure and the socio-cultural context in which they are used. While a good part of the course is based on Polish and English, examples are drawn from a wide range of other languages whenever possible. The course is divided into three parts. The introductory part deals with the different ways of classifying languages as well as problems involved in the analysis of language universals. The second part is concerned with a comparison of Polish and English with respect to their phonology, morphology, syntax and lexicon. The analysis of structural similarities and differences between the two languages allows students to discuss such phenomena as substratum transfer, borrowing and code-switching among Polish-English bilinguals. The final part deals with a variety of cultural, social and political issues. The analysis of cultural aspects focuses on, e.g., the reflection of cultural values in Polish and English as well as the hypotheses of linguistic determinism and relativity. As regards social issues, we discuss, e.g., the differences between Polish and English terms of address and the different representation of gender in the two languages. The course ends with a discussion of the role of prescriptive attitudes and the status of dialects in Poland, the British Isles and the United States.

\subsection{The John Paul II Catholic University of Lublin ${ }^{3}$}

The course is obligatory. Year 3, 30 contact hours, 1 ECTS point.

1. History of contrastive studies; the application of contrastive analysis in teaching a foreign language and in translation; the basic terminology (congruence, equivalence, tertium comparationis); the influence of $\mathrm{L} 1$ on L2; positive and negative transfer.

2 I start with the Adam Mickiewicz University in Poznań as it has the only Faculty of English in Poland, if not in Europe.

3 Since the conference was held at this university I think it fair enough to describe its course at this point. 
2. Phonetics and phonology: a comparison of the articulation of Polish and English sounds.

3. Phonetics and phonology: stress in Polish and English, a comparison of the selected phonological rules.

4. Morphology: prefixation and suffixation, reduplication, category change, back derivation.

5. Morphology: compounds, derivational base and its position in the selected languages.

6. Morphology: fore-clipping, back-clipping, middle-clipping (syncope), complex clipping, blending, acronyms.

7. Borrowings, doublets, calques.

8. Lexicon: lexical transfer, false friends.

9. Lexicon: confused words, semantic fields.

10. Selected grammatical categories.

11. Language typology: the role of flexion and word order.

12. The differences concerning parts of speech and parts of sentence.

13. Structural differences, syntactic structures and their counterparts.

14. Test.

15. Synopsis. ${ }^{4}$

\subsection{The Jagiellonian University in Kraków}

The course is obligatory. Year 2, 30 contact hours, 4 ECTS points.

Introduction to language comparison and an overview of selected topics in the contrastive English-Polish morphology, lexicon and syntax, including the inflectional categories of English and Polish, derivational morphology of English and Polish in contrast, English borrowings in Polish (adaptation processes and semantic fields), false friends, grammatical categories and constructions in contrast. Classes comprise a descriptive part and a practical part, where the phenomena discussed are illustrated with real language data and practiced in the form of exercises.

4 1. Historia badań kontrastywnych; zastosowanie wyników analizy kontrastywnej w nauczaniu obcego oraz przekładzie; podstawowa terminologia (kongruencja, ekwiwalencja, tertium comparationis); wpływ L1 na L2: transfer pozytywny i negatywny. 2. Fonetyka i fonologia: porównanie artykulacji głosek polskich i angielskich. 3. Fonetyka i fonologia: akcent w języku polskim i angielskim, porównanie wybranych reguł fonologicznych. 4. Morfologia: prefiksacja i sufiksacja, reduplikacja, przemiana kategorialna, derywacja wsteczna. 5. Morfologia: złożenia, podstawa słowotwórcza i jej pozycja w wybranych językach. 6. Morfologia: skróty aferezowe, apokopowe, synkopowe i eliptyczne, krzyżowanie (mieszanie) wyrazów, akronimy. 7. Zapożyczenia, dublety, kalki. 8. Leksykon: transfer leksykalny, false friends. 9. Leksykon: wyrazy często mylone, pola semantyczne. 10. Wybrane kategorie gramatyczne. 11. Typologia języków: rola fleksji i szyku wyrazów. 12. Różnice w zakresie części mowy oraz części zdania. 13. Różnice strukturalne, konstrukcje składniowe i ich odpowiedniki. 14. Test zaliczeniowy. 15. Podsumowanie kursu. 


\subsection{Pedagogical University of Cracow}

The course is obligatory. Year 2, 30 contact hours, 2 ECTS points.

1. The characterization of comparative studies. The basic terminology and their definitions.

2. Polish and English segmental phonetics: differences and interference.

3. Polish and English suprasegmental phonetics and phonology. Differences in phonological systems (on-line test).

4. Derivation: nominalization and lexicalization.

5. Derivation: ways of forming denominal and deverbal adjectives.

6. Derivation: aspect in Polish as a morphological category, aspect in English as a syntactic category.

7. Word formation: the most important word formation processes.

8. Verb flexion.

9. Noun flexion.

10. Conditional sentence.

11. Modal verbs.

12. Complements of the verb and adjective.

13. The passive voice and related structures.

14. Negation.

15. Sentence order. ${ }^{5}$

\subsection{University of Silesia}

The course is obligatory in the teaching specialization in the 1st and 2 nd cycles, whereas in the translation specialization it is offered only in the 1st cycle.

BA level: year 2, 15 contact hours, ECTS points not known.

1. History and future of contrastive studies.

2. Basic concepts: markedness, open-class and closed-class forms.

3. Aspect.

4. Negation (tests for negation, negative polarity items).

5. Definiteness (articles, pronouns, word order), there-insertion.

6. Voice (case and negation; Accusative, indirect and prepostional passive).

7. Gender (obligatoriness, arbitrariness, gender in implicational universals).

1. Charakterystyka badań porównawczych. Podstawowa terminologia i definicje. 2. Fonetyka segmentalna polska oraz angielska: obszary różnic, interferencja. 3. Fonetyka i fonologia ponadsegmentalna polska oraz angielska. Różnice w systemach fonologicznych (test online). 4. Derywacja: nominalizacja i leksykalizacja. 5. Derywacja: sposoby tworzenia przymiotników odrzeczownikowych i odczasownikowych. 6. Derywacja: aspekt w języku polskim jako kategoria morfologiczna, aspekt w języku angielskim jako kategoria składniowa. 7. Słowotwórstwo: najważniejsze procesy słowotwórcze. 8. Fleksja czasownika. 9. Fleksja rzeczownika. 10. Zdania warunkowe. 11. Czasowniki modalne. 12. Komplementacja czasownika i przymiotnika. 13. Strona bierna i konstrukcje pokrewne. 14. Negacja. 15. Szyk zdania. 
8. Alternations (Dative Alternation. Constraints in Polish and English).

9. Topics chosen by students (per assignments in: Student workload).

M.A. level: 30 hours of lectures, 30 hours of classes, ECTS points not known or the year in which it is taught.

1. A history of contrastive research, typology of linguistics studies $(2 \mathrm{~h})$.

2. The process of grammaticalization and grammatical categories in the world languages: an overview $(2 \mathrm{~h})$.

3. The basic forms of contrast between Polish and English (structural, categorial and functional) $(2 \mathrm{~h})$.

4. Differences between Polish and English on the level of the noun phrase, flexion (number, gender, case, definiteness), pronouns (6 h).

5. Differences between Polish and English on the level of the verb phrase, typology of verbs, modal verbs, flexion (tense, aspect, person, number, gender, mood, voice) (6 h).

6. Simple and complex sentences in Polish and English, the basic types of transformational processes.

7. Interrogative sentences in Polish and English, negation in both languages $(2 \mathrm{~h})$.

8. The passive voice in Polish and English, impersonal forms $(2 \mathrm{~h})$.

9. Existential sentences.

10. Contrastive pragmatics (speech acts, specialist registers) $(2 \mathrm{~h}){ }^{6}$

\subsection{University of Wroctaw}

The course is obligatory. Year 3, 30 contact hours, 3 ECTS points.

1. Aims and foundations of contrastive studies in linguistics.

2. Accounting for crosslinguistic variation via different parameter settings.

3. Word formation in contrast (affixation, compounding, internal modification, blending, acronyms, clipping, English borrowings in Polish).

4. Types of lexical contrast (lexical transfer, confusing words: each/every, as/like, make/do, say/tell/speak/talk, lie/lay, rise/raise/arise).

5. Adverbs and prepositions in English and Polish.

1. Historia badań kontrastywnych, typologia gałęzi językoznawstwa kontrastywnego, podstawowe zastosowania wyników badań kontrastywnych $(2 \mathrm{~h})$. 2. Proces gramatykalizacji i kategorie gramatyczne w językach świata: przegląd (2 h). 3. Podstawowe formy kontrastu pomiędzy językiem polskim i angielskim (strukturalny, kategorialny oraz funkcjonalny $(2 \mathrm{~h})$. 4. Różnice między językiem polskim i angielskim na poziomie frazy rzeczownikowej, odmiana (liczba, rodzaj, przypadek, określoność), zaimki (6 h). 5. Różnice między językiem polskim i angielskim na poziomie frazy czasownikowej, typologia czasowników, czasowniki modalne, odmiana (czas, aspekt, osoba, liczba, rodzaj, tryb, strona) (6 h). 6. Zdania proste i złożone w języku polskim i angielskim, podstawowe typy procesów transformacyjnych $(4 \mathrm{~h})$. 7. Zdania pytające w języku polskim i angielskim, formy negacji w obu językach $(2 \mathrm{~h})$. 8. Strona bierna w języku polskim i angielskim, formy bezosobowe $(2 \mathrm{~h}) .9$. Zdania egzystencjalne (2h). 10. Pragmatyka kontrastywna (badanie aktów mowy, rejestry specjalistyczne) $(2 \mathrm{~h})$. 
6. The Noun Phrase in English and Polish: word order, determiners, definiteness, adjectives, the genitive, gender, number.

7. The Verb Phrase in English and Polish: tenses, aspect, modality, conditional sentences, complementation, passive voice.

8. Word order in English and Polish.

9. Subject-verb agreement in English and Polish.

\subsection{University of Opole}

Unlike other universities the course is called Elements of contrastive linguistics. It is obligatory. Year 2, 30 contact hours, 3 ECTS points.

1. Contrastive research in linguistics.

2. Language typology (genetic and linguistic).

3. Language universals.

4. Contrastive analysis and tertium comparationis.

5. Cross-language contacts.

6. Cross-language transfer and some related problems.

7. Fundamental differences in the structure of Polish and English.

\subsection{University of Lodz}

The course is obligatory in teaching and translation specializations, 30 contact hours, the year and number of ECTS points are not known.

Basic concepts connected with comparing and contrasting languages; tenets of contrastive analysis; tertium comparationis; equivalence and congruence; English-Polish contrasts at phonetic, phonological, morphological and syntactic levels; language contact, vocabulary and borrowings; differences in semantics and pragmatics.

\subsection{University of Warsaw}

The course, called English-Polish contrastive syntax, is optional. No information concerning the year, 30 contact hours (format: lecture), 4 ECTS points.

1. Types of contrastive research, their function and application.

2. From hypothesis of contrastive analysis to research on the structure of interlanguage: evolution of psychological and linguistic principles of comparative linguistics.

3. Contrastive analysis in the generative model of first language acquisition; the so-called model of principles and parameters.

4. Lexicon structure, Theta criterion.

5. The role of flexion (declension paradigms) in Polish and English morpho-syntax.

6. X-bar syntax in the description of Polish and English nominal group. 
7. Exemplary contrastive analysis: passivization, raising construction, interrogative constructions.

8. Mechanisms of verifying contrastive hypotheses illustrated by pronominal anaphora.

9. Applied contrastive syntax: the passive voice, indirect speech, grammatical tenses.

10. Contrastive syntax in the pedagogical description of English grammar. ${ }^{7}$

\subsection{Nicolaus Copernicus University in Toruń}

There are two courses offered and they are obligatory. No information concerning the year they are taught, 30 contact hours, 2 ECTS points.

1. Introduction to contrastive studies $(2 \mathrm{~h})$.

- Basic types of linguistic contrasts (2 h).

- Derivational morphology in Polish and English $(4 \mathrm{~h})$.

- Comparison of selected semantic fields $(4 \mathrm{~h})$.

- Inflectional morphology in Polish and English $(2 \mathrm{~h})$.

- An outline of Polish and English syntactic systems (2 h).

- Polish-English contrasts in the verb phrase $(4 \mathrm{~h})$.

- Polish-English contrasts in the noun phrase (4 h).

- Polish and English pronominal systems $(2 \mathrm{~h})$.

- Text cohesion in Polish and English $(4 \mathrm{~h})$.

2. The first part of the course is designed to introduce the basic terminology used in contrastive linguistics as well as to locate contrastive linguistics on the spectrum of linguistic disciplines. The second part of the course in Contrastive grammar is devoted to discussing Polish-English morphological and syntactic contrasts. This process is accompanied by broadening students' knowledge of English.

\subsection{University of Warmia and Mazury in Olsztyn}

The course is obligatory. Year 3, 30 contact hours, 3 ECTS points.

The scope and aims of contrastive linguistics; Language families; Language universals and linguistic typology; Language contact; Descriptive and prescriptive approaches to language; Contrasting phonetics and phonology; Contrasting morphology; Contrasting syntax;

1. Rodzaje badań kontrastywnych, ich funkcje i zastosowanie. 2. Od hipotezy analizy kontrastywnej po badania nad strukturą interjęzyka: ewolucja psychologicznych i lingwistycznych założeń językoznawstwa porównawczego. 3. Analiza kontrastywna w generatywnym modelu akwizycji języka pierwszego: tzw. model zasad i parametrów. 4. Struktura leksykonu, kryterium Theta. 5. Rola fleksji (paradygmaty deklinacyjne) w polskiej i angielskiej morfo-składni. 6. Składnia kategorii wzmocnionych w opisie polskiej i angielskiej grupy nominalnej. 7. Przykładowe analizy kontrastywne: pasywizacja, konstrukcja podnosząca, konstrukcje pytające. 8. Mechanizmy weryfikacji hipotez kontrastywnych na przykładzie dystrybucji anafory zaimkowej. 9. Składnia kontrastywna stosowana: strona bierna, mowa zależna, czasy gramatyczne. 10. Składnia kontrastywna w pedagogicznym opisie gramatyki języka angielskiego. 
Contrasting lexicon; Languages and culture; Pragmatics; Language and society: Terms of address; Language and gender; Non-verbal communication.

This is an old syllabus. Nowadays it is taught in a way which seems to be unique in Poland. On the basis of Fisiak et al. (1978) the fundamental problems concerning syntax, morphology, phonology and semantics are discussed. ${ }^{8}$ This is followed by practical exercises based on two books that by: T. Pratchett and its Polish translation on the one hand, and that by A. Sapkowski and its English version, on the other.

\subsection{University of Bialystok}

Two courses are taught and both seem to be obligatory:

English-Polish contrastive grammar. Year 3, 15 contact hours, 1 ECTS point.

1. Introduction to contrastive linguistics (lecture 1).

- equivalence and congruence, types of equivalence (formal vs. dynamic)

2. Morphological contrast between English and Polish (lectures 2-5)

a) derivational morphology

- word formation processes in English and Polish

- English borrowings in Polish

b) inflectional morphology

- the categories of tense, aspect, mood, modality (verbs)

- the categories of number, case, gender (nouns, pronouns, adjectives, determines)

c) morphological errors made by Polish students of English (derivational, inflectional).

3. Syntactic contrast (lectures 6-10)

a) types of syntactic contrast (structural, functional, categorial)

b) word order in English and Polish (word order patterns, the position of adjectives and adverbs)

c) sentence elements in English and Polish (subjectless sentences in Polish, verb complementation)

d) concord: subject-verb agreement

e) common syntactic errors made by Polish students of English.

4. Lexical and semantic contrast (lectures 11-13)

a) types of semantic contrast (inclusion, overlapping, semantic contrast - 'false friends')

b) elements of cross-cultural semantics: culture-related differences between English and Polish lexicon (A. Wierzbicka)

c) Types of lexical errors.

5. Pragmatic contrast: speech acts in a contrastive perspective: making request, offers, invitations, apologies, giving advice; pragmatic errors (lectures 14-15).

Polish-English contrastive phonetics. 15 contact hours, 2 ECTS points, however, neither its content nor any information related to the year it is taught is available.

8 This order of topics has been indicated. 


\section{Conclusion}

All in all, we can conclude that in most cases the courses focus on the similarities and differences between English and Polish, especially on the lexical and grammatical levels, and occasionally on differences in pragmatics and semantics. They provide Polish students of English with knowledge that will be essential in their future professional careers either as teachers of English or translators and interpreters. However, hardly ever are the phonological and phonetic differences between the two languages in question considered, and the graphemic level of contrastive analysis is omitted in every case. Only in certain programmes are the semantic and pragmatic aspects included. At this point it should be noted that in our handbook (Willim, Mańczak-Wohlfeld 1997: 11) only the following areas of contrast are addressed:

- morphological, including differences stemming from the fact that English is an analytic while Polish is a synthetic language,

- lexical, including easily confused words, common collocations, prepositions,

- grammatical, including considerations of word order, subject-verb concord, the tenses.

However, these limitations are due to the size and scope of the work. Besides, since traditional structuralism is used as a point of reference, the semantic and pragmatic aspects are automatically excluded from consideration.

With regard to the courses discussed above it has to be noted that some are very ambitious and in a few cases one wonders whether it is feasible to cover so many topics. Occasionally, reference to world languages is suggested, which in fact goes beyond the scope of English-Polish contrastive grammar. Some programmes suggest starting the analysis with Polish before moving on to English, which is perhaps the right direction although it is contradictory with regard to the name of the subject because, as mentioned above, the course is usually called English-Polish contrastive grammar. The required and recommended bibliography differs, which is understandable considering the differences in the course content, although at most universities two books are included, namely Fisiak et al. (1978) as well as Willim and Mańczak-Wohlfeld (1997), which indicates that fairly outdated publications are used. Most probably this results from the fact that no other monograph or practical grammar book devoted to English-Polish contrastive grammar has been published more recently.

There are also many formal/technical differences between the courses. Most are called English-Polish contrastive grammar, unless indicated otherwise in the above discussion. Further differences concern the year it is studied, the number of contact hours, although a 30 $\mathrm{h}$ course is most common, the format (the class and lecture), and the number of ECTS points, which vary from 1 to 4 . Except for the University of Warsaw the course is obligatory and usually offered at the first cycle. Only at the University of Silesia is there a more advanced course for MA students.

As stated in the abstract and in section 1 the aim of the present paper is to suggest an "ideal" syllabus. It is fortunate as in fact I do not have to invent a programme as that offered 
at the University of Lodz more or less meets my expectations and even to a greater extent that of the John Paul II Catholic University in Lublin, which almost correlates with my idea of an "ideal" syllabus. This is because it covers not only almost all levels of language description but also contains a history of contrastive studies as well as the basic terminology used in this field. However, perhaps certain modifications could be introduced, namely the addition of EnglishPolish contrast on the graphemic level after point 3. Besides, I would suggest joining points 8 (Lexicon: lexical transfer, false friends) and 9 (Lexicon: confused words, semantic fields) and omitting both point 12 (The differences concerning parts of speech and parts of sentence) and point 15 (Synopsis, although the content of this part is not entirely clear). Instead I would suggest the introduction of semantic contrast, which could be placed after point 13 (Structural differences, syntactic structures and their counterparts), and could then be followed by pragmatic considerations with reference to English and Polish. Finally, I would prefer to start with English and contrast it with Polish to be consistent with the name of the course in question. However, whether teachers of English-Polish contrastive grammar will accept my proposal remains to be seen.

\section{References}

Fisiak, J., Lipińska-Grzegorek, M., and Zabrocki, T. 1978. An introductory English-Polish contrastive grammar. Warszawa: PWN.

Krzeszowski, T.P. 1990. Contrasting languages: The scope of contrastive linguistics. Berlin: Mouton de Gruyter.

Krzeszowski, T.P. 2011. English contrastive studies. From the fifteenth to the eighteenth century. Frankfurt/M: Peter Lang.

Willim, E., Mańczak-Wohlfeld, E. 1997. Contrastive approach to problems with English. Kraków: Wydawnictwo Naukowe PWN.

\section{Internet sources}

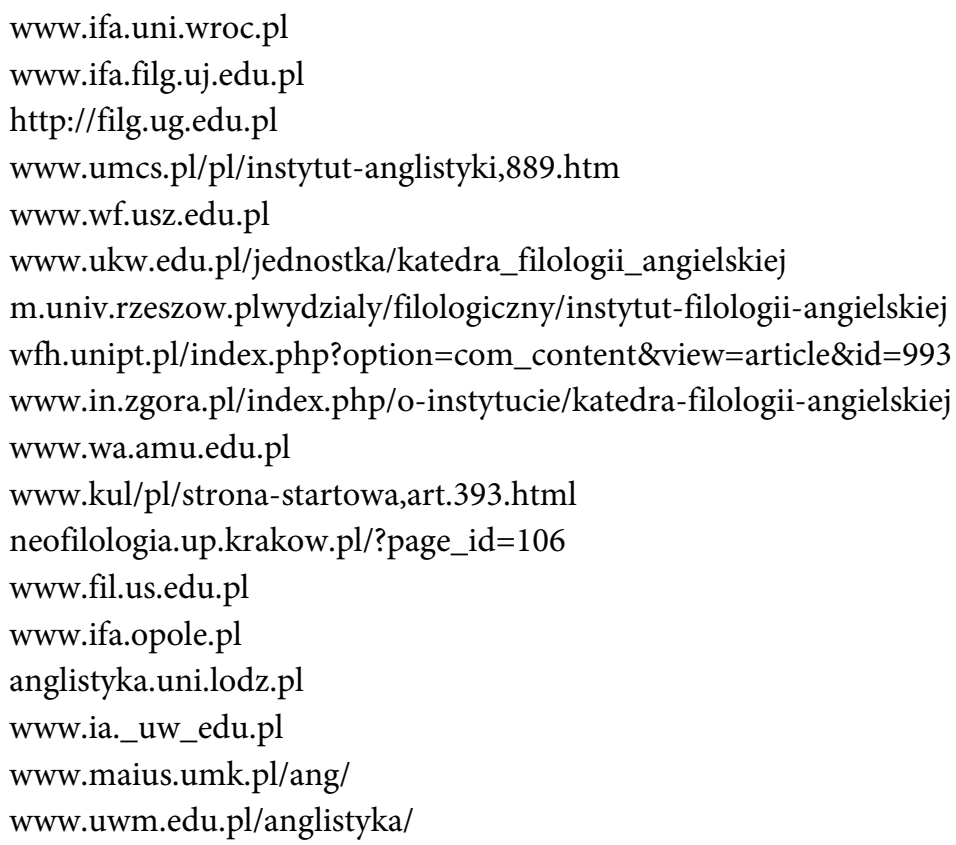

